\title{
Employers' Perspectives on the Performance of Higher Education Institutions in Preparing Graduates for the Workplace: A Review of the Literature
}

\author{
Matthew R. Hodgman \\ Department of Literature, American University \\ 4400 Massachusetts Ave NW, Washington, DC 20016, USA \\ Tel: 1-202-885-1000Ｅ-mail: hodgman80@hotmail.com
}

Received: July 10, 2018 Accepted: July 24, 2018 Published: July 27, 2018

doi:10.5296/ber.v8i3.13370 URL: https://doi.org/10.5296/ber.v8i3.13370

\begin{abstract}
Educational credentials play an important role in the job attainment process. To employers, academic credentials signal that a prospective employee has acquired certain competencies that certify readiness for the workplace. As grantors of educational credentials, higher education institutions (HEIs) are entrusted with the important duty of preparing graduates to enter the workforce. In order to better understand what employers need from HEIs in terms of preparing recent graduates for the workforce and the degree to which employers currently view the performance of HEIs in terms of preparing graduates to meet these needs, a review of the literature concerning employers' perceptions of HEI performance was conducted for the current study. Sources were reviewed and analyzed for reoccurring ideas or themes in the literature. Three themes emerged from the review: (a) the need for work-related skills, (b) the need for internships, and (c) skepticism toward for-profit higher education (FPHE) graduates. Suggestions for future research are offered based on the emergent themes. This study is beneficial to prospective college students, college administrators, employers, and higher education professionals and scholars.
\end{abstract}

Keywords: For-Profit Higher Education, Non-Traditional Students, Employers, Business Skills

\section{Introduction}

Educational credentials play an important role in the job search process. To employers, academic credentials signal that a prospective employee has acquired certain knowledge sets or competencies that certify readiness for the workplace (Brown, 2001). As grantors of 
educational credentials, higher education institutions (HEIs) are entrusted with the important duty of preparing graduates to enter the workforce. Employers must assess the value of the educational credentials held by prospective employees. Employers may determine the value of one's educational credentials based on several variables such as specific institutional reputation or the overall reputation of a specific educational sector (e.g., the for-profit higher education sector). There are significant differences between how well-suited graduates are for workplace success based on their held skill sets according to employers (Busteed \& Seymour, 2015). For this reason, some institutions are beginning to list acquired skill sets on college diplomas (Blumenstyk, 2015). Employers play a crucial role in determining the returns of formal education which necessitates an investigation of the role higher education plays in meeting employers' needs. The literature on the role HEIs play in meeting employers' needs gives insight into how well HEIs prepare students for the workforce and what employers believe HEIs need to generally do to produce employable graduates.

\section{Literature Review Methodology}

Fifteen academic databases relating to a combination of business, vocational, and higher education content were searched for authoritative peer-reviewed journal articles and research association documents related to employers' needs from HEIs in terms of preparing graduates to work and perceptions of the performance of HEIs in preparing recent graduates for the workforce. Examples of databases searched include: ERIC, Academic Search Premier, ABI/INFORM Complete, and Bloomberg Businessweek Archive. Quantitative and qualitative research studies conducted globally between 2007 and 2017 were consulted. In total, 87 relevant sources were consulted. Sources were reviewed and analyzed for reoccurring ideas or themes in the literature. The following themes emerged from the review of the literature: (a) the need for work-related skills, (b) the need for internships, and (c) skepticism toward for-profit higher education (FPHE) graduates.

\section{The Need for Work-related Skills}

Employers have expressed concern with the employability of recent college graduates (Goldschmidt, 2005; Hart Research Associates, 2013; Head, 2012; Maguire Research Associates, 2012; Stevens, 2005). Employers expect HEIs to provide graduating students with the skills and knowledge necessary to be successful in the workplace, yet recent graduates are not necessarily well-prepared for work according to employers. A Maguire Research Associates (2012) survey of employers who hired recent graduates found that $31 \%$ of employers indicated that recent graduates were unprepared or very unprepared for their job search, and over half of respondents indicated difficulty in finding qualified candidates for job openings. Much of the concern employers have with recent graduates pertains to the acquisition of needed work-related skills (Goldschmidt, 2005; Hart Research Associates, 2013; Kyng, Tickle, \& Wood, 2013; Lowden et al., 2011). Employers have identified several skill sets and experiences that HEIs should develop in students such as interpersonal skills (Hart Research Associates, 2013; Lowden et al., 2011; Maguire Research Associates, 2012; Stevens, 2005), ethical decision-making skills (English, Manton, Sami, \& Dubey, 2012; Jackson \& Chapman, 2012; Okoro, 2014), technological skills (Andrews \& Higson, 2008; 
Martinez, 2008; Seibold, 2007), intercultural skills (Hart Research Associates, 2013, 2015), and relevant work experience (Hart Research Associates, 2013; Lowden et al., 2011; Maguire Research Associates, 2012; Stevens, 2005).

\subsection{Interpersonal Skills}

Employees spend over $75 \%$ of their time in the workplace communicating (Akbari \& Shams, 2011). The literature illustrates that employers are not satisfied with the interpersonal skills (both written and oral) demonstrated by recent college graduates (Goldschmidt, 2005; Lowden et al., 2011; Maguire Research Associates, 2012; Stevens, 2005; Sundberg et al., 2011; Wye \& Lim, 2009). Specific interpersonal skills that employers believe graduates need but do not consistently possess include speaking skills (Stevens, 2005) and writing skills (Goldschmidt, 2005; Stevens, 2005; Sundberg et al., 2011).

\subsection{Speaking Skills}

In order to produce results in the workplace, employees must effectively communicate orally. Specifically, oral communication skills in English are important for employees to possess, especially in a global business world that uses English as its primary language of communication (Moslehifar \& Ibrahim, 2012). The significant use of oral communication skills in multinational companies was reported by $71 \%$ to $80 \%$ of employers (Kassim \& Ali, 2010). Important workplace speaking skills include telephone etiquette (Akbari \& Shams, 2011; Kassim \& Ali, 2010), interviewing skills (Maguire Research Associates, 2012; Stevens, 2005), presentation skills (Conrad \& Newberry, 2012; Stevens, 2005), and negotiation skills (Wye \& Lim, 2009). Despite the importance of oral communication, employers report that there are significant gaps between the oral communication expectations of industries and what HEIs offer to students (Moslehifar \& Ibrahim, 2012; Smith, 2000); this gap is attributed to the failure of HEIs to align their programs with the needs of the workplace (Abraham \& Karns, 2009; Ghannadian, 2013; Martinez, 2008; Stevens, 2005).

\subsection{Writing Skills}

Writing skills have also been identified by employers as being important for workplace success. Research shows that workers fall short of employers' expectations for written communication skills in the workplace (College Board, 2003; Goldschmidt, 2005; Stevens, 2005; Sundberg et al., 2011). Writing skills are among the largest skills gap reported by employers when assessing new graduates (Archer \& Davison, 2008). Remedying writing deficiencies costs American corporations as much as $\$ 3.1$ billion annually, and sending a single worker for remedial training in writing can cost more than $\$ 3,000$ (College Board, 2004). Written communication skills germane to the workplace include sending emails, drafting reports, and producing presentations (College Board, 2003; Sundberg et al., 2011). Specific written communication skills that employers report need improvement include professional email skills, skills regarding self-expression, vocabulary usage, and the avoidance of slang (Stevens, 2005). 


\subsection{Ethical Decision-making Skills}

Furthermore, employers believe employees must have the ability to make ethical decisions at work (Jackson \& Chapman, 2012; Okoro, 2014; Zakariaa, Bidin, \& Ismaila, 2014). Ethical employees are those who make decisions in the best interests of themselves, their employers, their coworkers, and outside stakeholders. Workplace ethics center on such diverse issues as discrimination, fraud, theft, and personal politics (Ingram, n.d.). A Hart Research Associates (2015) study found that while $62 \%$ of students believed they were well prepared for the ethical decision-making demands of the workplace, only $30 \%$ of employers believed this was the case. Ethical employees are financially valuable to their employers as they contribute to building trusting relationships, team cohesiveness, and personal wellness by enabling open and honest communication and by not hindering group progress through unethical activity (Ingram, n.d.).

\subsection{Technological Skills}

Further still, employers desire employees who possess current technological skills (Andrews \& Higson, 2008; Martinez, 2008; Ghannadian, 2013; Kyng et al., 2013). As of 2013, one of every three employees was a millennial (i.e., an individual born between 1980 and 2000); within 10 years, millennials are expected to constitute $75 \%$ of the workforce (Randstad Technologies, 2015). Employers within all industries are restructuring their companies to accommodate a "millennial shift" or a reshaping of workplace technologies and operating norms in line with the expectations of the millennial generation (Randstad Technologies, 2015 , p. 2). Some of the millennial technologies that are frequently utilized in the workplace include mobility, cloud, big data, virtualization, security management, and social media applications (Randstad Technologies, 2015). Despite the need for recent college graduates to have modern technological skills, only $37 \%$ of employers believe that recent college graduates are well-prepared for the technological demands of the workplace (Hart Research Associates, 2015). Specifically, employers believe that students are not being taught important computer and systems integration skills necessary for workplace success (Martinez, 2008).

\subsection{Intercultural Skills}

Finally, employers desire employees who possess intercultural skills (Hansen \& Hansen, 2015; Hart Research Associates, 2013, 2015; National Association of Colleges and Employers, 2012). Intercultural skills involve competencies related to being aware of and sensitive to other people and cultures (Hansen \& Hansen, 2015). With increased diversity in the workplace and a multicultural emphasis in society, intercultural skills have become an important asset across industries (Holt, n.d.). Cultural awareness and sensitivity enhances communication, productivity, and unity in the workplace. Employees with intercultural skills bring in new clients, work well within diverse teams, and support a good brand and reputation. The risks associated with not having employees who possess strong intercultural skills include loss of clients, damage to an organization's reputation, team conflict, and financial implications (Mulholland, 2013). 
Specific intercultural skills employers believe employees must possess include building rapport with a diverse workforce (Hansen \& Hansen, 2015), possessing knowledge of other cultures (Holt, n.d.), being aware of one's own culture (Mulholland, 2013), overcoming stereotypes (Holt, n.d.), demonstrating multilingual capabilities (Mulholland, 2013), and experiencing diverse cultures outside the workplace (Hart Research Associates, 2015). Although $48 \%$ of recent college graduates said they were aware of diverse cultures in the US, only $21 \%$ of employers believed graduates were culturally aware (Hart Research Associates, 2015). Relative to being aware of diverse cultures outside the US, $42 \%$ of recent college graduates reported they were culturally aware, where only $15 \%$ of employers agreed that college graduates were culturally aware (Hart Research Associates, 2015). These statistics suggest that there is room for improvement in terms of helping students develop intercultural skills for the workplace. Despite reporting gaps between the skills employees possess and the needs of industry, employers have several suggestions concerning how HEIs can better equip graduates with these skills.

\subsection{Addressing Work-related Skill Deficiencies}

Employers are frustrated that the courses HEIs offer do not meet their needs; even when sitting on curricular development committees, employers claim that institutions disregard their views on course design (Lowden et al., 2011). To help students more sufficiently develop the skills employers desire, employers suggest that HEIs do the following: (a) more closely align academic programs with employer needs (Kassim \& Ali, 2010; Moslehifar \& Ibrahim, 2012), (b) increase the rigor of writing standards (Stevens, 2005), (c) provide students with more opportunities to speak in public and receive feedback on presentations (Stevens, 2005), (d) sharpen students' problem-solving skills (Jackson \& Chapman, 2012; Maguire Research Associates, 2012; Wye \& Lim, 2009), (e) teach interview skills (Maguire Research Associates, 2012), (f) emphasize professional ethics in lectures and through institution-sponsored workshops (Okoro, 2014), (g) enforce technology literacy as a requirement for college graduation, (h) change the technological curriculum design at HEIs to further align with workforce needs (Martinez, 2008), (i) encourage the study of foreign languages and overseas study (Mulholland, 2013), (j) encourage curricula aimed at improving students' intercultural awareness and intercultural communicative competence (Wu, 2014), and (k) put employability at the center of strategic planning both centrally and at the individual department level (Lowden et al., 2011). In addition to specific skills, employers express a need for employees to have relevant work internships prior to graduating from college.

\section{The Need for Internships}

Employers frequently report that college graduates would benefit from having meaningful work experience in their intended work fields through internships prior to graduation (Hart Research Associates, 2013; Helyer \& Lee, 2014; Lowden et al., 2011). After a review of relevant work studies, California State University concluded that work experience became more crucial in hiring starting in 1980. By 1993, 93\% of interns in work-study programs were offered jobs by their employers, according to a Northwestern University study (Baker, 2013). 
A survey by the Institute for Public Policy Research found that the unemployment rate among those who gained work experience through internships while studying was $14 \%$ compared with up to $23 \%$ for those who left education without work experience through internships (Henderson, Schmuecker, \& Baker, 2013).

The desire for pre-graduate work experiences is based on the idea that said work experience will help students successfully transition to the workplace by developing employment skills, building content knowledge, and instilling an awareness of employer culture in students prior to graduating (Hart Research Associates, 2013; Lowden et al., 2011). Performing well in pre-graduation work situations can lead to positive outcomes, such as recommendations for graduate school or a full-time job offer, and can give interns a chance to work with others and learn about job skills that need improvement (Baker, 2013).

\subsection{Addressing the Need for Internships}

In order to gain relevant work experience prior to graduation, employers consistently suggest that HEIs assist students in securing internships (Hart Research Associates, 2013; Helyer \& Lee, 2014; Lowden et al., 2011; Maguire Research Associates, 2012). The combination of subject knowledge and relevant workplace experience that an internship can offer provides a catalyst for future employee innovation, development, and success (Helyer, \& Lee, 2014). When assessing several important attributes in graduates while making hiring decisions across major work industries, employers report internships as the most important attribute necessary for workplace success (Maguire Research Associates, 2012). Nearly half the recruiters in a study of the graduate market stated that graduates with no previous work experience at all were unlikely to be successful during the selection process (Highfliers, 2015). Internships are most beneficial to employers when secured in fields directly related to students' major fields of study. Recruiters rate resumes with relevant experience as more attractive than resumes with experience that is unrelated and perceive that applicants with both paid and volunteer experience are more suitable than applicants with only paid or volunteer experience and that both paid and unpaid internship experiences are highly valued by employers (Wilkin \& Connelly, 2012). Recruiters also suggest that entry-level applicants craft their resumes to emphasize the types of experiences and skills that recruiters find most desirable; applicants should emphasize the skills they have developed in their limited work experience rather than simply listing any type of work experience (Wilkin \& Connelly, 2012). Although employers clearly state their needs from HEIs in terms of providing graduates with successful skill sets and work experiences, the literature suggests that there is a specific level of skepticism that employers feel concerning the ability of for-profit higher education institutions (FPHEIs) to meet the needs of the workplace.

\section{Skepticism toward For-Profit Higher Education Graduates}

Although the literature above highlights employers' general needs from higher education and higher education graduates, several studies have specifically attempted to investigate the role FPHEIs play in meeting employers' needs. When compared to nonprofit colleges, FPHEIs and their graduates are generally considered less desirable by employers (Darolia et al., 2014; Deming et al., 2014) or employers are neutral about their beliefs (Public Agenda, 2014; 
Seibold, 2007). For example, when faced with fictitious resumes listing an FPHE relative to those whose resumes listed either a community college or no college at all, employers showed no indication that they preferred applicants who attended sector institutions when work experience was held constant; estimates suggest that employers prefer applicants from community colleges (Darolia et al., 2014). In addition, relative to comparisons between FPHE attendees and high school graduates, there is no evidence that job applicants benefit from attending sector institutions (Darolia et al., 2014). Job applicants with resumes indicating bachelor's degrees in business from an FPHE were nearly $22 \%$ less likely to get a callback than applicants with similar degrees from nonselective public institutions; job applicants from local brick-and-mortar FPHEIs were less likely to get callbacks compared with those who held degrees from public schools (Deming et al., 2014). The limited literature suggests that there are negligible labor market benefits to attending sector institutions, especially in comparison to nonprofit public institutions such as community colleges.

\section{Need for Additional Research}

The literature on the role of HEIs in meeting employers' needs is lacking in terms of research methodology and both research population and topical matter. In terms of methodology, additional research is needed that employs specific qualitative approaches. Few studies have explored the role of higher education in meeting employers' needs solely through a qualitative research approach. Certain studies have incorporated qualitative methodologies as part of a mixed-methods approach, but few have only relied on a qualitative approach. For example, Goldschmidt (2005) used an interview methodology to explore hiring managers' perceptions of new bachelor's graduates and followed up with a telephone survey. Further, Lowden et al. (2011) used a two phase approach consisting of an interview phase and a case study phase to explore the employability skills of new graduates. More qualitative research is needed to collect rich, broad data and to give voice to employers as they explain their views of the returns of higher education in the workplace in detail. Qualitative research might specifically take the form of a longitudinal study in order to gauge how employers' opinions and ideas concerning HEIs change over time and more thoroughly understand the potentially complex motivations and reasons that undergird these opinions.

In addition, research focused on exploring different populations and topical areas pertaining to the role HEIs play in meeting employers' needs is needed. For example, more research is needed to better understand how HEIs use varying course delivery formats to meet employers' needs in different work fields and disciplines. Adams and DeFleur (2006) explored the acceptability of online degrees earned as a credential for obtaining employment through the eyes of hiring supervisors. This work could be extrapolated to focus on employers' perceptions of online degrees earned in specific work fields such as healthcare or manufacturing or further research might focus on investigating how employers in varying work disciplines or geographic areas view the role specific course delivery formats such as online, hybrid, and face-to-face formats specifically play in terms of preparing graduates for successful entry to the workplace.

In order to more deeply explore employer perspectives of HEI performance from a more 
diverse range of perspectives, future research might investigate employers perceptions from the vantage points of study populations from different racial, ethnic, cultural, or age backgrounds for example. This type of research could be carried further to explore how employers' from diverse backgrounds view the performance of HEIs in terms of addressing the areas of need identified in the current study, namely, developing specific important work-related skills and internship competencies in students.

Future research surrounding employers' perceptions might importantly focus on exploring the degree to which employers believe HEIs assist graduates in solely cultivating specific work-related skills such as technological skills or writing skills. It will also be important to know more about the specific suggestions employers might have for HEIs in terms of better preparing graduates for work. For example, it would be significant to better understand how employers might specifically direct HEIs to better develop ethical decision-making skills or speaking skills in students. It would also be important to investigate employers' perceptions of how HEIs might better prepare graduates for work interviews or teamwork situations. Still further, it would be insightful to better understand how employers feel HEIs might help prepare graduates for jobs that might not even exist yet as changes in the labor market dictate new job opportunities and the acquisition of new skill sets endemic to those jobs.

Finally, additional research is needed that focuses more specifically on the role different sectors of higher education play in meeting employers' needs. A majority of the research within the literature focuses on the role HEIs generally play in meeting the demands of the workplace. Yet, there is a growing body of literature that particularly explores employers' perceptions of the job different higher education sectors are doing in terms of preparing students for the workforce. Studies, such as those conducted by Darolia et al. (2014) and Deming et al. (2014), focus on gauging employers' perceptions of FPHEIs in comparison to traditional nonprofit institutions or to having no college credentials at all. As the current study suggests, additional research is needed that focuses on why and to what degree employers may harbor skepticism toward FPHEIs and their graduates and also why employers might prefer to hire graduates from certain higher education sectors over graduates from other sectors. Research is needed that not only focuses solely on perceptions of FPHEIs but also concerning why, how, and the degree to which employers assess HEIs from different sectors comparatively. This type of research might help HEIs from different sectors more specifically understand how to better prepare their graduates for work.

\section{References}

Abraham, S. E., \& Karns, L. A. (2009). Do business schools value the competencies that businesses value?. Journal of Education for Business, 84(6), 350-356.

https://doi.org/10.3200/JOEB.84.6.350-356

Adams, J., \& DeFleur, M. (2006). The acceptability of online degrees earned as a credential for obtaining employment. Communication Education, 55(1), 32-45.

https://doi.org/10.1080/03634520500343376

Akbari, A. F., \& Shams, Y. (2011, May 15). Oral communication in workplace. Retrieved 
from http://www.unitar.org/hiroshima/sites/unitar.org.hiroshima/files/6b.\%20Oral\%20Communicat ion\%20Presentation.pdf

Andrews, J., \& Higson, H. (2008). Graduate employability, "soft skills" versus "hard" business knowledge: A European study. Higher Education in Europe, 33(4), 411-422. https://doi.org/10.1080/03797720802522627

Archer, W., \& Davison, J. (2008). Graduate employability: What do employers think and want?. Retrieved from http://www.brunel.ac.uk/services/pcc/staff/employability/?a=92718

Baker, T. (2013, August 14). Why gaining work experience is more important than your education. Chicago Tribune. Retrieved from

http://articles.chicagotribune.com/2013-08-14/business/sns-201308141600--tms--brazenctnbc -c20130814-20130814_1_work-experience-internship-job-lead

Blumenstyk, G. (2015). When a degree is just the beginning. Retrieved from

http://chronicle.com/article/When-a-Degree-Is-Just-the/232969/

Brown, D. K. (2001). The social sources of educational credentialism: Status cultures, labor markets, and organizations. Sociology of Education, 74, Extra Issue: Current of Thought: Sociology of Education at the Dawn of the 21st Century, 19-34.

https://doi.org/10.2307/2673251

Busteed, B., \& Seymour, S. (2015). Many college graduates not equipped for workplace success. Retrieved from

http://www.gallup.com/businessjournal/185804/college-graduates-not-equipped-workplace-s uccess.aspx

College Board. (2003). The National Commission on Writing for America's Families, Schools, and Colleges. The neglected " $r$ ": The need for a writing revolution. Retrieved from

http://www.collegeboard.com/prod_downloads/writingcom/neglectedr.pdf

College Board. (2004). The National Commission on Writing for America's Families, Schools, and Colleges. Writing: A ticket to work.. . . . or a ticket out, a survey of business leaders. Retrieved from

http://www.collegeboard.com/prod_downloads/writingcom/writing-ticket-to-work.pdf

Conrad, D., \& Newberry, R. (2012). Identification and instruction of important business communication skills for graduate business education. Journal of Education for Business, 87(2), 112-120. https://doi.org/10.1080/08832323.2011.576280

Darolia, R., Koedel, C., Martorell, P., Wilson, K., \& Perez-Arce, F. (2014). Do employers prefer workers who attend for-profit colleges? Evidence from a field experiment. CALDER Working Paper No. 116. The National Center for Analysis of Longitudinal Data in Education Research. https://doi.org/10.2139/ssrn.2508434

Deming, D. J., Yuchtman, N., Abulafi, A., Goldin, C., \& Katz, L. F. (2014). The value of postsecondary credentials in the labor market: An experimental study (Working Paper No. 20528). Washington, DC: The National Bureau of Economic Research. 
https://doi.org/10.3386/w20528

English, D., Manton, E. J., Sami, A. R., \& Dubey, A. (2012). A comparison of the views of college of business graduate and undergraduate students on qualities needed in the workplace. College Student Journal, 46(2), 427-435.

Ghannadian, F. F. (2013). What employers want, what we teach. Retrieved from http://www.bizedmagazine.com/features/articles/what-employers-want-what-we-teach.asp

Goldschmidt, N. P. (2005). Lessons learned from surveying employers. Assessment Update: Progress, Trends, and Practices in Higher Education, 17(4).

Hansen, R. S., \& Hansen, K. (2015). What do employers really want? Top skills and values employers seek from job-seekers. Retrieved from

http://www.quintcareers.com/job-skills-values/

Hart Research Associates (2013). It takes more than a major: Employer priorities for college learning. Retrieved from

https://www.aacu.org/sites/default/files/files/LEAP/2013_EmployerSurvey.pdf

Hart Research Associates. (2015). Falling short?: College learning and career success. Retrieved from

https://www.aacu.org/sites/default/files/files/LEAP/2015employerstudentsurvey.pdf

Head, A. J. (2012, October). Learning curve: How college graduates solve information problems once they join the workplace. Project Information Literacy Research Report.

Helyer, R., \& Lee, D. (2014). The Role of Work Experience in the Future Employability of Higher Education Graduates. Higher Education Quarterly, 68(3), 348-372.

https://doi.org/10.1111/hequ.12055

Henderson, G., Schmuecker, K., \& Baker, R. (2013). Northern skills for national prosperity: The rationale for localising the skills system in England. Retrieved from

http://www.ippr.org/files/images/media/files/publication/2013/02/northern-skills-130220-web \%202_10358.pdf?noredirect $=1$

Highfliers. (2015). The graduate market in 2015: Annual review of graduate vacancies \& starting salaries at Britain's leading employers. Retrieved from

http://www.highfliers.co.uk/download/2015/graduate_market/GMReport15.pdf

Holt, M. (n.d.). Culture awareness in the workplace. Retrieved from

http://smallbusiness.chron.com/culture-awareness-workplace-737.html

Ingram, D. (n.d.). How do ethics make you a better person in the workplace? Retrieved from http://smallbusiness.chron.com/ethics-make-better-person-workplace-11979.html

Jackson, D., \& Chapman, E. (2012). Non-technical competencies in undergraduate business degree programs: Australian and UK perspectives. Studies in Higher Education, 37(5), 541-567. https://doi.org/10.1080/03075079.2010.527935 
Kassim, H., \& Ali, F. (2010). English communicative events and skills needed at the workplace: Feedback from the industry. English for Specific Purposes, 29, 168-182. https://doi.org/10.1016/j.esp.2009.10.002

Kyng, T., Tickle, L., \& Wood, L.N. (2013). Perceptions of the software skills of graduates by employers in the financial services industry. International Journal of Mathematical Education in Science and Technology, 44(8), 1224-1238.

https://doi.org/10.1080/0020739X.2013.770092

Lowden, K., Hall, S., Elliot, D., \& Lewin, J. (2011, May/June). Employers'perceptions of the employability skills of new graduates. University of Glasgow SCRE Centre and Edge Foundation, 1-28.

Maguire Research Associates. (2012, December). The role of higher education in career development: Employer perceptions.

Martinez, J. (September, 2008). Employers' Satisfaction and Perceptions of the Technological Skills Required for the Workforce. (Doctoral dissertation) Retrieved from ProQuest Dissertation database. (3320027).

Moslehifar, M. A., \& Ibrahim, N. A. (2012). English language oral communication needs at the workplace: Feedback from human resource development (HRD) trainees. Social and Behavioral Sciences, 66, 529-536. https://doi.org/10.1016/j.sbspro.2012.11.297

Mulholland, J. (2013, March 4). Why employers value intercultural skills. Retrieved from http://www.britishcouncil.org/voices-magazine/why-employers-value-intercultural-skills

National Association of Colleges and Employers. (2012). Job outlook 2013 survey. Washington, DC: Author.

Okoro, J. (2014). Employers' assessment of work ethics required of university business education graduates in south-south Nigeria. College Student Journal, 48(3), 437-444.

Public Agenda. (2014, February). Profiting higher education? What students, alumni, and employers think about for-profit colleges. Retrieved from

http://kresge.org/sites/default/files/Edu-LibraryProfitingHigherEducation_PublicAgenda_201 4.pdf

Randstad Technologies. (2015). Preparing for the millennial shift: IT infrastructures adapt to the changing workforce with "millennial-friendly" technologies. Retrieved from https://www.randstadusa.com/workforce360/workforce-insights/top-10-ways-millennials-aretransforming-it-departments/270/

Seibold, K. S. (2007, February 12). Employers' perceptions of online education. (Doctoral dissertation). Retrieved from

http://dc.library.okstate.edu/utils/getfile/collection/Dissert/id/73378/filename/74069.pdf

Smith, M. C. (2000). What will be the demands of literacy in the workplace in the next millennium?. Reading Research Quarterly, 35(3), 378-380. 
https://doi.org/10.1598/RRQ.35.3.3

Stevens, B. (2005). What communication skills do employers want? Silicon valley recruiters respond. Journal of Employment Counseling, 42, 2-8.

https://doi.org/10.1002/j.2161-1920.2005.tb00893.x

Wilkin, C., \& Connelly, C. (2012). Do I look like someone who cares? Recruiters' ratings of applicants' paid and volunteer experience. International Journal of Selection and Assessment, 20(3), 308-318. https://doi.org/10.1111/j.1468-2389.2012.00602.x

$\mathrm{Wu}$, J. (2014). On the principles and contents of culture teaching in college English. Asian Journal of Humanities and Social Sciences, 2(2), 142-152.

Wye, C. K., \& Lim, Y. (2009). Perception differential between employers and undergraduates on importance of employability skills. International Education Studies, 2, 95-105. https://doi.org/10.5539/ies.v2n1p95

Zakariaa, M. H., Bidin, Y., \& Ismaila, S. (2014). A new approach in measuring graduate employability skills. AIP Conference Proceedings, 1602(1), 1202-1208.

https://doi.org/10.1063/1.4882637

\section{Copyright Disclaimer}

Copyright for this article is retained by the author(s), with first publication rights granted to the journal.

This is an open-access article distributed under the terms and conditions of the Creative Commons Attribution license (http://creativecommons.org/licenses/by/3.0/). 